\title{
The Effectiveness of Albendazole-Levamisole and Mebendazole-Levamisole on the Intensity of Trichuris trichiura Infection in Elementary School Children
}

\author{
Endy Juli Anto'), Jekson Martiar Siahaan²), Hendrika Andriana Silitonga3) \\ ${ }^{1)}$ Department of Parasitology, Faculty of Medicine,Universitas Methodist Indonesia, Medan \\ 2)Department of Physiology, Faculty of Medicine,Universitas Methodist Indonesia, Medan \\ 3)Department of Histology, Faculty of Medicine,Universitas Methodist Indonesia, Medan
}

\section{ABSTRACT}

Background: Trichuris trichiura worm infection is still a major public health problem in Indonesia, especially in peripheral areas. Until now, the search for antihelmintic combinations that have a high healing ability against $T$. trichiura infections and in the search for truly effective worming is still being done. Albendazole and Mebendazole single doses still show limited efficacy in the treatment of $T$. trichuria worms. The combination of Albendazole with Levamisol can increase effectiveness, but this combination still needs further investigation. Based on that fact, it is necessary to study the effectiveness comparison of the degree of infection intensity between the treatment of Albendazol-Levamisol and Mebendazol-Levamisol against $T$. trichiura .

Subjects and Method: A double blind randomized control trial was conducted at the State Elementary School in Medan, North Sumatera, from April to October 2019. A sample of 60 children was selected for this study. The dependent variable was the number of eggs decreased, the cure rate, and side effects. The independent variables were Albendazole $400 \mathrm{mg}$-Levamisol 50 $\mathrm{mg} / 100 \mathrm{mg}$ and Mebendazole 500 mg-Levamisol $50 \mathrm{mg} / 100 \mathrm{mg}$. The stools of elementary school children were examined using the Kato-Katz method to find eggs of $T$. trichiura infection. Data analysis was performed using the Chi square test.
Results: Samples in the Albendazol-Levamisol and Mebendazol-Levamisol groups were 30 children, respectively. Children infected with $T$. trichiura consisted of 58 children of mild intensity (96.7\%) and 2 children of moderate intensity (3.3\%). On the results of stool examination, a significant difference in the number of eggs decreased in the two groups was obtained ( $p$ $<0.001$ ) and $96.7 \%$ was the cure rate for $T$. trichiura infection in the two groups of Albendazol-Levamisol and Mebendazol-Levamisol. In this study, there were no significant differences in side effects in the two treatment groups.

Conclusion: Treatment of $T$. trichiura infection with single doses of Albendazol-Levamisol and Mebendazol-Levamisol showed that there were significant differences in the Number of Decreased Eggs. Meanwhile, for the cure rate, there was no difference between the AlbendazolLevamisol and Mebendazol-Levamisol groups.

Keywords: $\quad T$. trichiura, AlbendazoleLevamisol, Mebendazole-Levamisol

\section{Correspondence:}

Endy Juli Anto. Department of Parasitology, Faculty of Medicine, Universitas Methodist Indonesia, Medan, Indonesia. Email: dr.endyjulianto@gmail.com. Mobile: +62-823 6766-7575

Cite this as:

Anto EJ, Siahaan JM, Silitonga HA (2020). The Effectiveness of Albendazole-Levamisole and MebendazoleLevamisole on the Intensity of Trichuris trichiura Infection in Elementary School Children. Indones J Med. 5(1): 17-23. https://doi.org/10.26911/theijmed.2020.05.01.03

(c) (7) Indonesian Journal of Medicine is licensed under a Creative Commons

Attribution-Non Commercial-Share Alike 4.o International License. 


\section{BACKGROUND}

Intestinal helminth disease is still a major public health problem in Indonesia, especially in rural areas. In Indonesia and in various developing countries, Ascaris lumbricoides, Trichuris trichiura and hookworm are intestinal parasites of the nematode group that most often cause infections. An estimated 4.5 billion individuals are at risk of STH, of whom 1.2 billion may be infected with $A$. lumbricoides, nearly 800 million are infected with $T$. trichiura, and more than 700 million are infected with hookworms. More than $60 \%$ of children in Indonesia suffer from worm infections.

According to data from the North Sumatra Provincial Health Office, about 32\% of North Sumatra's population suffers from worms, and about $87 \%$ of elementary school students in Deli Serdang suffer from worms. Many species of worms have been reported to cause infections in Indonesia. T. trichiura which lives in the human cecum is the most difficult cause of intestinal worms and one of the most important intestinal nematodes in humans. This helminthiasis is classified as a neglected disease, which is an infection that is lacking in attention and is chronic without causing clear clinical symptoms and the resulting impact is only seen in the long term. The T. trichiura worm is the most difficult to treat, which if usually infected by 2 other worms (Ascaris lumbricoides and hookworm) once taking medication immediately healed. However, T. trichiura has to take medicine three days in a row before it can show improvement (Beth Monkey al., 2006; Dent and Kazura, 2007; CDC, 2013).

In the management of infections, $T$. trichiura worm commonly used drug albendazol or mebendazol which can eradicate helminthiasis with each of the advantages and disadvantages. But in its implementation, it is still unsatisfactory in its treatment. Therefore in this study, it was used to see the effectiveness comparison of the drug combination of the albendazole-levamisol group with mebendazole-levamisol against $T$. trichiura worm infections.

\section{SUBJECTS AND METHOD \\ 1. Study Design}

This was double blind randomized trial, which compared the effectiveness of Albendazol-Levamisol and Mebendazol-Levamisol dosis alone against Trichuris trichiura infection.

The study was conducted at the Parasitology Laboratory of the Faculty of Medicine, Methodist University of Indonesia. To check the number of worm eggs in the stool before and after treatment, this is done by the Kato-Katz method.

\section{Population dan Sample}

The study population was elementary school children in Medan (Belawan and Tembung Districts) who were infected by Trichuris trichiura. Students selected as samples were children who tested positive for being infected by Trichuristrichiura based on the results of stool examinations in the laboratory by the Kato Katz method.

A sample of 60 children divided into two groups (Albendazol-Levamisol and Mebendazol-Levamisol) were selected for this study.

\section{Study Variables}

The dependent variable is the Number of Decreased Eggs (APJT) and the cure rate and side effects. The independent variables are Albendazol-Levamisol and Mebendazol-Levamisol.

\section{RESULTS}

This study was conducted on students of public elementary schools in the city of Medan carried out starting in April and October 2019. The number of students was 251 people. Of the 216 students who returned the pots, 6363 positive elementary school 
Anto et al./ The Effectiveness of Albendazole-Levamisole and Mebendazole-Levamisole

students suffered from Trichuris trichiura infection through the Kato-katz examination. Of the 63 elementary school children, only 60 elementary school children met the study criteria, then randomly divided into 2 groups with group I (Albendazol $400 \mathrm{mg}$ with single- dose Levamisol one day), 60 children of elementary school and group II (Mebendazol $500 \mathrm{mg}$ with a single dose of Levamisole one day) which is 60 children of elementary school students. The profile of the study can be seen in Figure 1.

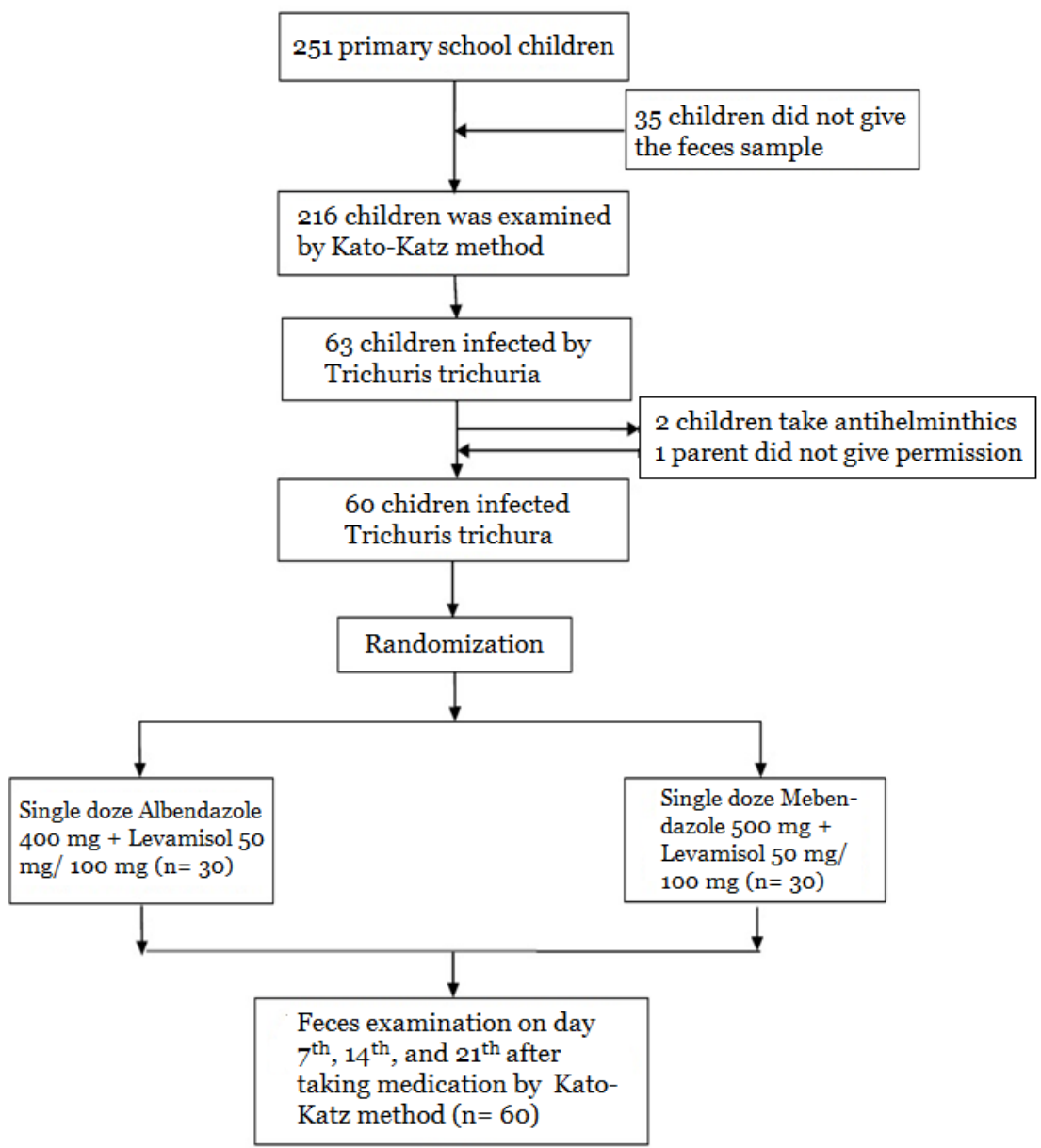

Figure 1. Study Profile

Table 1. Sample Characteristics

\begin{tabular}{|c|c|c|c|}
\hline Characteristics & $\begin{array}{c}\text { Albendazol- } \\
\text { Levamisol } \\
\text { n(\%) }\end{array}$ & $\begin{array}{c}\text { Mebendazol- } \\
\text { Levamisol } \\
\text { n(\%) }\end{array}$ & $\mathbf{p}$ \\
\hline \multicolumn{4}{|l|}{ Gender } \\
\hline Male & $16(53.3)$ & $14(46.7)$ & 0.606 \\
\hline Female & $14(46.7)$ & $16(53 \cdot 3)$ & \\
\hline \multicolumn{4}{|l|}{ Infection Intensity } \\
\hline Mild & $30(100)$ & $28(93.3)$ & \\
\hline Moderate & $O(0)$ & $2(6.7)$ & \\
\hline \multicolumn{4}{|l|}{ Nutritional Status } \\
\hline Poor & $15(50.0)$ & $25(83.3)$ & 0.018 \\
\hline Good & $15(15.0)$ & $5(16.7)$ & \\
\hline
\end{tabular}


Anto et al./ The Effectiveness of Albendazole-Levamisole and Mebendazole-Levamisole

Table 1 shows that there were more male respondents than female respondents in the Albendazole-Levamisol group. Male respondents totaled 16 children (15.3\%) and female respondents totaled 14 children (46.7\%). Meanwhile, the number of males in the single-dose Mebendazole-Levamisol group was 14 children (46.7\%) and women were 16 (53.3\%).

The intensity of the infection is divided into mild and moderate infections. In $T$. trichiura infection the Albendazol-Levamisol combination drug group with a single dose of 30 children (100\%) suffered from a mild in- fection, while the Mebendazol-Levamisol single dose combination drug group had 29 children (96.7\%) suffering from a mild infection and 1 child ( $3.3 \%)$ have a moderate infection.

Nutritional status is divided into malnutrition and good nutrition. In the singledose Albendazol-Levamisol group, there were 15 children (50\%) who were undernourished, 15 children (50\%) had good nutrition. Meanwhile, the single-dose Mebendazol-Levamisol group consisted of 25 children (83.3\%) malnourished, and 5 children (16.7\%) good nutrition.

Table 2. Results of analysis of the number of STH eggs on Albendazol-Levamisol and Mebendazol-Levamisol on Day 21 After Treatment

\begin{tabular}{lcccc}
\hline \multicolumn{1}{c}{ Intervention } & $\mathbf{n}$ & $\begin{array}{c}\text { Average Drop } \\
\text { Rate of Eggs }\end{array}$ & SD & p \\
\hline Albendazol-Levamisol & 30 & 3.2 & 17.52 & 0.001 \\
Mebendazol-Levamisol & 30 & 12.0 & 65.72 & \\
\hline
\end{tabular}

Table 2 shows that there were significant APJT differences in both groups for albendazole-levamisole $($ Mean $=3.2 ; \mathrm{SD}=$ 17.52) and mebendazole-levamisol (Mean = 12 ; $\mathrm{SD}=65.72$ ) with $\mathrm{p}=0.001$ on the 21st day after treatment.

In table 3 , observation of the $7^{\text {th }}$ day, after the administration of a single dose of Albendazol-Levamisol combination, as many as 2 children $(6.7 \%)$ were not cured $(6.7 \%)$ and Mebendazol-Levamisol was given as a single dose, children who did not recover were 2 children $(6.7 \%)$. On the $14^{\text {th }}$ day of observation, after giving a single dose of Albendazol-Levamisol combination, 2 children (6.7\%) were not recovered and 6.7 (single dose of Mebendazol-Levamisol) showed that 1 child (3.3\%) did not recover .

Table 3. The results of the analysis of single dose Albendazol-Levamisol and Mebendazol-Levamisol on the cure rate of STH infections on the $7^{\text {th }}, 14^{\text {th }}$ and $21^{\text {st }}$ days

\begin{tabular}{lccc}
\hline \multicolumn{1}{c}{ Day } & $\begin{array}{r}\mathbf{N} \\
\text { cured }\end{array}$ & Cured proportion & p \\
\hline Day 7 & 28 & & \\
$\quad$ Albendazol-Levamisol & 28 & 93.3 & 1.000 \\
$\quad$ Mebendazol-Levamisol & 28 & 93.3 & \\
Day 14 & 29 & 93.3 & 0.584 \\
$\quad$ Albendazol-Levamisol & & 96.7 & \\
$\quad$ Mebendazol-Levamisol & 29 & 96.7 & 1.000 \\
Day 21 & 29 & 96.7 & \\
$\quad$ Albendazol-Levamisol & & & \\
Mebendazol-Levamisol & & &
\end{tabular}


Anto et al./ The Effectiveness of Albendazole-Levamisole and Mebendazole-Levamisole

At the observation of the $21^{\text {st }}$ day after giving a single dose of Albendazol-Levamisol combination where the child who did not recover was as much as 1 (3.3\%) and giving a single dose of Mebendazol-Levamisol combination where the child who did not recover was as much as 1 child $(3.3 \%)(\mathrm{p}=1.000)$. The results of all observations showed that the comparison of $T$. trichiura infections with mild to moderate intensity, from the two groups giving Albendazol 400 mg-Levamisol $50 \mathrm{mg} / 100 \mathrm{mg}$ and the combination of Mebendazol 50omg-Levamisol 50mg/100mg single dose did not show significant differences in cure rates.

Table 4 shows almost no difference between side effects in the two groups of drugs ( $\mathrm{p}>0.050)$.

\section{Table 4. Side Effects of Albendazol-Levamisol and Mebendazol-Levamisol}

\begin{tabular}{lccc}
\hline \multirow{2}{*}{ Characteristics } & \multicolumn{2}{c}{ Side Effects } & \multirow{2}{*}{ p } \\
\cline { 2 - 3 } & $\begin{array}{c}\text { Negative } \\
\text { n(\%) }\end{array}$ & $\begin{array}{c}\text { Positive } \\
\text { n(\%) }\end{array}$ & \\
\hline Albendazol-Levamisol & $22(73.3)$ & $8(26.7)$ & 0.095 \\
Mebendazol-Levamisol & $27(90.0)$ & $3(10.0)$ & \\
\hline
\end{tabular}

\section{DISCUSSION}

Helminthiasis due to STH infection is still a major health problem for the people of Indonesia. A. lumbricoides, T. trichiura and hookworms (N. americanus and A. Duodenale) are the most common types of worms (Shumbejet al., 2015). WHO data (2012) shows that the area of North Sumatera is a relatively high degree of STH infection with a prevalence in the range of more than $80 \%$ for school-age children.

Comprehensive treatment through government programs in the field of health and individually against helminth infections has been carried out, but the incidence of infection with this disease is still high. Conversely, research by conducting health education and environmental interventions can reduce the number of worm infections in the community. It turns out that treatment alone without changes in Knowledge, Attitudes and Health Practices (PSP), can not reduce the reinfection rate of this worm infection (Strickland, 2000; Donkor and Lunberg, 2009).

On stool examination by the Kato-Katz method, a decrease in the number of eggs was seen in all groups of Albendazol-Levamisol, Mebendazol-Levamisol until the 21st day. Statistical analysis with chi square on day 21 showed that the Albendazol-Levamisol and Mebendazol-Levamisol groups showed the effect of decreasing the number of eggs of different Trichuris trichiura $(\mathrm{p}<0.05)$. This is in contrast to study by Anto and Nugraha (2019), which found that APJT was not significant between Albendazol, Albendazol-Levamisol and Mebendazol-Levamisol in T. Trichiura infection on day 21 after treatment $(\mathrm{p}=0.247)$.

Another study by Saputri (2010) showed that APJT was significant in the single dose Mebendazole group and MebendazolLevamisol both in T. trichiura infection after treatment. Whereas the study of Sihite, et al. (2014) showed that there was no significant difference in APJT in the single-dose Mebendazole group with the Mebendazol-Levamisol combination in STH infections. Study by Knopp, et al. (2010), states that there is no significant effect on APJT in the Albendazol and Mebendazol groups. In the 21st day study, the same cure rate was $96.7 \%$ (Table 3 ). Statistical analysis with chi square on day 21 of the Albendazol-Levamisol and Mebendazol-Levamisol groups did not show a significant difference with $\mathrm{p}=1.000$ for the cure rate $(\mathrm{p}>0.050)$. 
All results showed that $\mathrm{T}$. trichiura infection from the two groups of the drug AlbendazolLevamisol and Mebendazol-Levamisol showed no significant difference in AP (cure rate). This is similar to Julianto study (2017), which states that there is no significant difference in AP in the Albendazol, Albendazol-Levamisol and Mebendazol-Levamisol groups in $\mathrm{T}$. trichiura infection $\mathrm{p}=0.136$.

Study conducted by Sihite et al. (2014) noted that there was no significant difference in cure rates for STH infections in the Mebendazol-Levamisol group compared to Mebendazol. According to Saputri in 2010, there was no significant difference in the cure rate.

Side effects found for the three groups after treatment were found by researchers only in the form of nausea and diarrhea. Comparison of side effects found in the Albendazol-Levamisol and Mebendazol-Levamisol groups were $26.7 \%$ and $10 \%$, respectively (Table 4). This study used the 400mg Albendazol drug (Albendazol, PT. Indofarma), 500mg Mebendazole (Vermox 500®, Janssen-Cilag) and Levamisol (Askamex, Konimex). The results obtained showed that there were no links or sponsorship messages from the three drug trade names.

Helminthiasis due to STH infection is still a major health problem for elementary school children, especially in T. trichiura. In this study, it was found the most for milddegree infection intensity. Use of Albendazole 400mg-Levamisol 5omg/ 100mg, Mebendazol 50omg-Levamisol 5o/ 100mg and single dose Albendazol 400mg showed significant differences in terms of decreasing number of eggs in general after 21st day treatment.

As for the cure rate for STH infections, there were no significant differences between the two groups after 21st day treatment. In this study, side effects were found in the form of nausea and diarrhea in the comparison of the two treatment groups.

\section{AUTHOR CONTRIBUTION}

The contribution of researchers in this study is as main researcher and a member of this research who play a role in designing and drafting, providing socialization, collecting samples, conducting examinations, preparing reports, presentations and reports.

\section{CONFLICT OF INTEREST}

The authors declare that the study was conducted in the absence of any commercial or financial relationships that could be construed as a potential conflict of interest.

\section{FUNDING AND SPONSORSHIP}

This research was funded by the Director of Research and Community Service (DRPM) Ministry of Research, Technology and Higher Education (Kemenristekdikti) in the 2019 budget year.

\section{ACKNOWLEDGEMENT}

The authors would like to thank the Ministry of Research, Technology and Higher Education DRPM for the assistance of Beginner Lecturer Research. The author expressed his gratitude for the trust given to the research team.

\section{REFERENCE}

Anto EJ, Nugraha SE (2019). Efficacy of Albendazole and Mebendazole With or Without Levamisole for Ascariasis and Trichuriasis. Open Access Maced J Med Sci, 7(8):1299-1302. https://-doi.org/10.3889/oamjms.2019.299.

Amelia F, Ali M, Pasaribu S (2013). Mebendazole vs Mebendozole-Pyrantel Pamoate for soil-transmitted helminthiasis infection in children. Pediatrica Indonesiana, 53: 209-13.

BethonyJ, Brooker S, Alboniko M, Geiger SM, Loukas A, Diemert D, Hotez PJ (2006). Soil transmitted helminth infections: ascariasis, trichuriasis, and hookworm. Lancet, 367: 1521-32.

Centers for Disease Control and Prevention (2013).Trichuriasis. USA: Centers for 
Anto et al./ The Effectiveness of Albendazole-Levamisole and Mebendazole-Levamisole

Disease Control and Prevention Available from: http://www.dpd.cdc.gov/$\mathrm{dpdx} / \mathrm{HTML} /$ Trichuriasis. html.

Dent AE, Kazura JW(2007). Trichuriasis (Trichuris trichiura). In: Berhman RE, Kleighman RM, Jenson HB editors, Nelsons textbook of pediatric, Edisi 13. Philadelphia: Saunders: 1499-1500.

Dinas Kesehatan Provinsi Sumatera Utara (2013). Profil kesehatan provinsi Sumatera Utara.

Donkor KA, Lunberg S (2009). Trichuris trichiura. Retrieved from http://www.emedicine/D:/SP.htm.

Julianto E (2017). Perbandingan efikasi dan efek samping antara albendazol, albendazol-levamisol dan mebenda-zollevamisol terhadap infeksi soil-transmitted helminths pada anak usia sekolah dasar negeri Kabupaten Deli Serdang (Comparison of the efficacy and side effects between albendazol, albendazol-levamisol and mebendazol levamisol against soil-transmitted helminths infections in state primary school age children in Deli Serdang Regency). Jurnal Ilmu Kefarmasian Indonesia, 15(2): 167-173.

Kazura JW (2000). Helminthic disease. In: Berhman, RE, Kliegman, RM, Jenson H.B editors, Nelson Textbook of pediatric, Edisi ke-16. Philadelphia: Saunders.

Keisser J, Utzinger J (2008). Efficacy of current drugs againts soil-transmitted helminth infection, systematic review and meta-analysis. JAMA, 299:193748.
Knopp S, Mohammed KA, Speich B, Hattendorf J, Khamis IS, Khamis AN, Stothard JR, et al. (2010). Albenda-zole and mebendazole administered alone or in combination with ivermec-tin against trichuris trichiura: A randomized controlled trial. Clinical Infectious Diseases, 51(12): 1420-1428.

Saputri D (2009). Perbandingan efikasi dosis tunggal mebendazol dengan dan tanpa levamisol terhadap soil-transmitted helminths pada anak usia sekolah dasar (Comparison of the efficacy of a single dose of mebendazole with and without levamisol against soil transmitted helminths in primary school-aged children). Tesis. Medan: Universitas Sumatera Utara.

Sihite IF, Ali M, Pasaribu AP, Pasaribu S, Lubis CP (2014). Efficacy of mebendazole and levamisole, alone or in combination, for soil-transmitted helminthiasis. Pediatrica Indonesiana, 54: 914.

Shumbej T, Belay T, Mekonnen Z, Tefera T, Zemene E (2015). Soil-transmitted helminths and associated factors among pre-school children in Butajira Town. South-Central Ethiopia: A CommunityBased Cross-Sectional Study. PLOS ONE, 10(8): e0136342.

Strickland G (2000). Trichuriasis. In: Hunter's Tropical Medicine WB, Saunders Editor, Edisi ke-8. Philadephia.

WHO (2012). Research priorities for helminth infection. WHO Techn Rep Series, WHO Bull. 